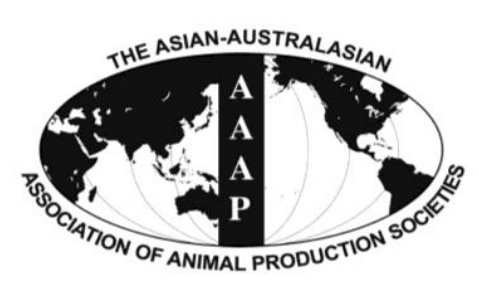

\title{
Effects of Benzoic Acid and Dietary Calcium:Phosphorus Ratio on Performance and Mineral Metabolism of Weanling Pigs
}

\author{
A. Gutzwiller*, P. Schlegel, D. Guggisberg, and P. Stoll
}

Federal Research Institute Agroscope, 1725 Posieux, Switzerland

\begin{abstract}
In a $2 \times 2$ factorial experiment the hypotheses tested were that the metabolic acid load caused by benzoic acid (BA) added to the feed affects bone mineralization of weanling pigs, and that a wide dietary calcium (Ca) to phosphorus (P) ratio in phytasesupplemented feeds with a marginal $\mathrm{P}$ concentration has a positive effect on bone mineralization. The four experimental diets, which contained $0.4 \% \mathrm{P}$ and were supplemented with $1,000 \mathrm{FTU}$ phytase $/ \mathrm{kg}$, contained either $5 \mathrm{~g} \mathrm{BA} / \mathrm{kg}$ or no BA and either $0.77 \% \mathrm{Ca}$ or $0.57 \% \mathrm{Ca}$. The 68 four-week-old Large White pigs were fed the experimental diets ad libitum for six weeks and were then slaughtered. Benzoic acid increased feed intake $(p=0.009)$ and growth rate $(p=0.051)$, but did not influence the feed conversion ratio $(p>0.10)$. Benzoic acid decreased the $\mathrm{pH}$ of the urine $(\mathrm{p}=0.031)$, but did not affect breaking strength and mineralization of the tibia ( $>0.10)$. The wide Ca:P ratio decreased feed intake $(p=0.034)$ and growth rate $(p=0.007)$ and impaired feed the conversion ratio $(p=0.027)$, but increased the mineral concentration in the fat-free DM of the tibia $(p=0.013)$ without influencing its breaking strength $(p>0.10)$. The observed positive effect of the wide Ca:P ratio on bone mineralization may be attributed, at least in part, to the impaired feed conversion ratio, i.e. to the higher feed intake and consequently to the higher mineral intake per $\mathrm{kg} \mathrm{BW}$ gain. The negative impact on animal performance of the wide dietary $\mathrm{Ca}: \mathrm{P}$ ratio outweighs its potentially positive effect on bone mineralization, precluding its implementation under practical feeding conditions. (Key Words: Benzoic Acid, Calcium, Bone Characteristics, Pig)
\end{abstract}

\section{INTRODUCTION}

Pig slurry contributes to the environmental pollution by phosphorus $(\mathrm{P})$ and nitrogen, part of which is evaporated as ammonia. In regions with a high pig density, pig feeds commonly contain low amounts of $\mathrm{P}$ in order to minimize $\mathrm{P}$ output and are supplemented with phytase to improve intestinal $\mathrm{P}$ absorption. Ammonia emission from pig slurry can be reduced by supplementing the feed with benzoic acid (BA). Benzoic acid inhibits microbial ammonia formation via its metabolite hippuric acid, which is formed in the liver and excreted in the urine (Hansen et al., 2007). Benzoic and hippuric acid contribute to the metabolic acid load and may therefore affect bone integrity, because chronic acidosis stimulates bone resorption by osteoclasts and compromises

\footnotetext{
* Corresponding Author: A. Gutzwiller. Tel: +41-26-407-72-23, Fax: +41-26-407-73-00, E-mail: andreas.gutzwiller@agroscope. admin.ch

Submitted Aug. 22, 2013; Accepted Nov. 19, 2013; Revised Jan. 7, 2014
}

bone mineralization (Arnett, 2003). In an experiment reported by Gutzwiller et al. (2011), BA intake had a negative effect on the bone markers alkaline phosphatase (AP) and crosslaps in the serum of pigs weighing $25 \mathrm{~kg}$ which were fed a phytase supplemented diet with a low $\mathrm{P}$ concentration, which indicates that BA disturbed bone metabolism, but later on, at $60 \mathrm{~kg} \mathrm{BW}$, neither the bone markers nor bone mineralization were affected by BA. The normal bone mineralization of the animals slaughtered at 60 $\mathrm{kg}$ BW does not preclude that bone mineralization at a younger age had been impaired because compensatory bone mineralization may occur during the growing period (Fammatre et al., 1977). In order to verify the hypothesis based on blood traits that BA intake impairs bone metabolism in weanling pigs fed a diet with a low $\mathrm{P}$ concentration, the animals of the present experiment were slaughtered at $23 \pm 4 \mathrm{~kg} \mathrm{BW}$, six weeks after weaning.

The dietary calcium (Ca):P ratio influences bone mineralization, too. The National Research Council (NRC, 2012) suggests a Ca:P ratio for grain-soybean meal diets

Copyright $@ 2014$ by Asian-Australasian Journal of Animal Sciences This is an open-access article distributed under the terms of the Creative Commons Attribution Non-Commercial License (http://creativecommons.org/licenses/by-nc/3.0/) which permits unrestricted non-commercial use, distribution, and reproduction in any medium, provided the original work is properly cited. 
between 1.1:1 and 1.25:1 based on the argument that a wide $\mathrm{Ca}: \mathrm{P}$ ratio lowers $\mathrm{P}$ absorption, growth performance and bone mineralization. The finding of Lantzsch et al. (1995) and Létourneau-Montminy et al. (2010) that increasing the Ca:P ratio from $1.3: 1$ to $1.9: 1$ in diets supplemented with a high amount of phytase increased $\mathrm{P}$ retention and bone mineralization in weanling pigs, is in contradiction to the NRC recommendation. In these two balance studies the digestibility of both $\mathrm{Ca}$ and $\mathrm{P}$ was $70 \%$, resulting in a ratio of absorbed $\mathrm{Ca}$ to absorbed $\mathrm{P}$ which corresponded to the dietary $\mathrm{Ca}: \mathrm{P}$ ratio. Because the ratio of $\mathrm{Ca}: \mathrm{P}$ retained in the body of growing pigs is 1.65:1 (Crenshaw, 2001), Ca absorbed from the phytase supplemented diets with a $\mathrm{Ca}: \mathrm{P}$ ratio of $1.3: 1$ presumably became the limiting factor for bone mineralization. The negative effects of the wide dietary Ca:P ratio on growth performance stated by the NRC (2012) could not be verified in the balance studies of Lantzsch et al. (1995) and of Létourneau-Montminy et al. (2010) because feed intake of the pigs had been restricted. In the present study the effects of two Ca:P ratios in phytase supplemented diets on growth performance and bone traits were therefore studied in ad libitum fed weanling pigs kept in groups. Because BA increases the absorption, but also the renal excretion of $\mathrm{P}$ (Gutzwiller et al., 2011) and may therefore interact with the effects of the dietary $\mathrm{Ca}: \mathrm{P}$ ratio, the effects of both factors were studied together in a $2 \times 2$ factorial experiment.

\section{MATERIALS AND METHODS}

The experiment was approved by the animal welfare department of the canton of Fribourg, Switzerland (approval number FR 4/10).

\section{Experimental design and diets}

The effects of two factors, BA and dietary $\mathrm{Ca}$ concentration, were examined in a $2 \times 2$ factorial experiment using 32 female and 36 castrated male weanling pigs. Groups of four littermates of the same gender with a similar BW were blocked. Each pig within a block was randomly assigned to one of the four dietary treatments. The four experimental diets had the same $\mathrm{P}$ concentration, but either a high ( $\mathrm{HCa}$ ) or a low (LCa) Ca concentration. Diets $\mathrm{HCa}-$ and $\mathrm{LCa}-$ contained no BA. For the production of diets $\mathrm{HCa}+$ and $\mathrm{LCa}+$ containing $0.5 \% \mathrm{BA}, 2.5 \mathrm{~kg} \mathrm{BA}$ (VevoVitall, DSM Nutritional Products Ltd., Basel, Switzerland) plus the amount of ingredients necessary for the production of $500 \mathrm{~kg}$ diets $\mathrm{HCa}$ - and $\mathrm{LCa}$ - respectively were mixed in the feed mill during the feed blending process.

Based on the analyzed DM, CP, crude fat, crude fiber and ash content of the batches of ingredients available for blending the feeds plus feed table data of their mineral and apparent digestible $\mathrm{P}(\mathrm{dP})$ content and their digestible amino acid composition the diets were formulated to have the same energy and nutrient content, except for $\mathrm{Ca}$. The formulated dietary nutrient content corresponded to the Swiss recommendations for pigs weighing $15 \mathrm{~kg}$ (Agroscope Liebefeld-Posieux, 2004) except for their lower than recommended apparent total tract $\mathrm{dP}$ content of $0.27 \%$, which was calculated using the tabulated $\mathrm{P}$ digestibility data of the ingredients (Agroscope Liebefeld-Posieux, 2004) and a dP equivalence of $1.2 \mathrm{~g}$ for the 1,000 FTU of added phytase/kg diet (Kornegay, 2001). The four experimental diets were mixed in the feed mill of the institute using ingredients of the same batch. The meal was pelleted at $70^{\circ} \mathrm{C}$ in order to prevent thermal inactivation of native and supplemented phytase. The dietary electrolyte balance $(\mathrm{dEB})$, expressed as milliequivalents $(\mathrm{mEq}) / \mathrm{kg}$ diet, was calculated by subtracting $\mathrm{mEq}$ chloride $(\mathrm{Cl}) / \mathrm{kg}$ from the sum of $\mathrm{mEq}$ sodium $(\mathrm{Na}) / \mathrm{kg}$ plus $\mathrm{mEq}$ potassium $(\mathrm{K}) / \mathrm{kg}$.

\section{Animals and husbandry conditions}

The 68 Large White pigs weighing on average $9.7 \mathrm{~kg}$ entered the experiment on the day of weaning at the age of four weeks. They were equipped with transponders for individual identification by the computer controlled feeding station and were transferred to four identical pens (one per treatment) with $7 \mathrm{~m}^{2}$ slatted floor and $10 \mathrm{~m}^{2}$ concrete floor with straw bedding, which were situated in one room of a climate controlled building. Each pen was equipped with one feeding station (Schauer, Prambachkirchen, Austria) having one feed trough for the feeding of one pig per visit. Visiting piglets were identified and could eat from the trough standing on a scale which registered feed disappearance per visit. The pelleted diets were available $\mathrm{ad}$ libitum during the experiment lasting 41 days. Three nipple drinkers per pen provided tap water. The technical installations and the piglets were checked daily by the attendants.

\section{Experimental procedures}

Feed samples were collected at the end of each experimental week, and the six samples of each diet were pooled for nutrient analysis. The pigs, which had constant access to feed and water until the end of the experiment, were weighed weekly and at the end of the experiment. Within two hours after the last weighing they were killed at the slaughterhouse situated on the premises of the research institute. They were stunned with $\mathrm{CO}_{2}$, and at sticking blood samples were collected into tubes without anticoagulant. During evisceration urine samples were collected from the bladder of 33 animals ( $\mathrm{HCa}+9$ pigs; $\mathrm{HCa}-\mathrm{LCa}+\mathrm{LCa}-\mathrm{s}$ pigs per treatment); the bladders of 35 animals contained no urine. The blood samples were centrifuged within two hours after collection. Both tibiae 
were collected within half a day after slaughter, manually cleaned of adhering tissue and packed in sealed plastic bags. The bones, serum and urine samples except the samples for urinary $\mathrm{pH}$ determination were stored at $-20^{\circ} \mathrm{C}$ until they were analyzed.

\section{Laboratory procedures}

Urine $\mathrm{pH}$ was determined within half an hour after collection using a Metrohm pH 691 meter (Metrohm, Zofingen, Switzerland). The left tibiae were transferred from the freezer to a refrigerator having a temperature of $10^{\circ} \mathrm{C} 16 \mathrm{~h}$ before their breaking strength was determined using the three point bending test. The bones were held on a testing machine (Zwick Roell, Ulm, Germany) by two supports spaced $49 \mathrm{~mm}$ apart and were broken by a wedge lowered on the centre of the bone at a speed of $10 \mathrm{~mm} / \mathrm{min}$. The peak of maximum force was recorded. After autoclaving the right tibiae at $121^{\circ} \mathrm{C}$ and 1 atmosphere during $45 \mathrm{~min}$, the adhering soft tissue was removed, the bones were crushed, bathed for four hours in acetone under constant stirring for defatting and ground through a $3 \mathrm{~mm}$ screen. Samples of defatted ground bone and of feed were dried at $105^{\circ} \mathrm{C}$ for the determination of the DM. Bone and feed samples were ashed in a muffle furnace at $550^{\circ} \mathrm{C}$. The ashed bone and feed samples were solubilized in 10 molar nitric acid, and their $\mathrm{Ca}, \mathrm{P}$, magnesium $(\mathrm{Mg}), \mathrm{Na}$ and $\mathrm{K}$ concentrations were analyzed according to EN 15510:2007 using an inductively coupled plasma optical emission spectrometer (ICP-OES, Optima 2000 DV, Perkin-Elmer, Schwerzenbach, Switzerland). Phytate phosphorus in the diets was analyzed using the kit K-Phyt 12/12 (Megazyme, Bray, Ireland). Dietary chloride concentration was analyzed using the argentometric titration method. CP was analyzed using the Dumas method on a Leco FP-2000 analyzer (Leco, Mönchengladbach, Germany). For amino acid determination, the feed samples were prepared according to the Commission Regulation (EC) 152:2009 and were analyzed by HPLC (Alliance 2695, Waters, Milford, MA, USA) as described in the manufacturer's manual (Waters AccQ Tag Chemistry Package 052874 TP, rev. 1). Crude fiber and crude fat were analyzed according to the VDLUFA methods 6.1.4 and 5.1.1. Phytase activity in the feeds was measured using the ISO 30024 method (Gizzi et al., 2008). One FTU corresponds to the amount of enzyme that releases $1 \mu \mathrm{mol} \mathrm{P}$ from $5 \mathrm{mM}$ phytate/min at $\mathrm{pH} 5.5$ and $37^{\circ} \mathrm{C}$. The serum and urine analytes were assayed on an Cobas Mira analyzer (Roche, Basel, Switzerland) at $37^{\circ} \mathrm{C}$, using kit 1489216 for Ca (Roche, Basel, Switzerland), 61571 for P (BioMérieux, Marcy l'étoile, France), 11489291 for creatinine (CREA Roche) and 2172933 for alkaline phosphatase (AP; Roche).

\section{Statistical analysis}

The individual pig served as the experimental unit. The data were analyzed with the ANOVA procedure of the statistics package NCSS 2007 (Hintze, Kaysville, Utah, USA) using the general linear model. The model included $\mathrm{BA}(+,-)$, dietary $\mathrm{Ca}$ concentration $(\mathrm{HCa}, \mathrm{LCa})$ and the $\mathrm{BAxCa}$ interaction as fixed factors, and block as random factor. The block effect was not included in the model for the analysis of the urine variables because of missing data. Because the pigs of treatments $\mathrm{HCa}$ had a significantly lower final $\mathrm{BW}$ and consequently also smaller, mechanically less resistant tibiae than the pigs of treatments $\mathrm{LCa}$, the force necessary to break the tibia was divided by the $\mathrm{BW}$ of the corresponding animal, and the corrected data as well as the actually measured data were statistically analyzed. Differences at $\mathrm{p} \leq 0.05$ were considered statistically significant, whereas differences with $0.10 \geq p>0.05$ were considered as tendency.

\section{RESULTS}

The formulation and the chemical composition of the experimental diets are shown in Table 1 and 2, respectively. The analyzed nutrient levels corresponded to the formulated levels. Phytase activity in diets $\mathrm{HCa}+$ and $\mathrm{HCa}$ - was $23 \%$ and $32 \%$ higher than in diets LCa diets. The calculated dietary $\mathrm{dP}$ concentration amounted to $0.27 \%$.

\section{Growth performance}

Benzoic acid increased feed intake $(p=0.009)$ and ADG ( $p=0.051)$, but did not influence the feed conversion ratio (FCR, $\mathrm{p}>0.10$; Table 3 ). The pigs fed the $\mathrm{HCa}$ diets had a reduced feed intake $(\mathrm{p}=0.034)$, a reduced ADG $(\mathrm{p}=$ $0.007)$ and an impaired FCR $(\mathrm{p}=0.027)$.

\section{Serum and urine variables}

Benzoic acid lowered the urinary $\mathrm{pH}(\mathrm{p}=0.031)$, but neither influenced $(p>0.10)$ the other urine nor the serum variables (Table 4). The pigs fed the $\mathrm{HCa}$ diets had an increased serum $\mathrm{Ca}(\mathrm{p}<0.001)$ and a decreased serum $\mathrm{Mg}(\mathrm{p}$ $=0.002)$ and $\mathrm{P}(\mathrm{p}<0.001)$ concentration, whereas serum alkaline phosphatase activity was unaffected $(p>0.10)$. The diets $\mathrm{HCa}$ increased the urinary $\mathrm{Ca} /$ creatinine ratio $(\mathrm{p}=$ $0.006)$, but not the $\mathrm{P} /$ creatinine ratio $(\mathrm{p}>0.10)$.

\section{Bone traits}

Benzoic acid did not influence $(p>0.10)$ any of the bone traits (Table 5). The mineral concentration in the bone DM was increased $(\mathrm{p}=0.013)$, and $\mathrm{Mg}$ concentration in the bone ash was decreased $(\mathrm{p}<0.001)$ in the pigs fed the $\mathrm{HCa}$ diets, whereas the breaking strength of their bones did not differ $(p>0.10)$ from that of the pigs fed the LCa diets. 
Table 1. Composition of the experimental diets with $0.77 \%$ calcium ( $\mathrm{HCa}$ ) and $0.57 \%$ calcium ( $\mathrm{LCa}$ ) respectively, as fed basis

\begin{tabular}{lcc}
\hline Ingredients (\%) & Diet HCa & Diet LCa \\
\hline Corn, ground & 42.8 & 43.7 \\
Barley, ground & 25.2 & 25.5 \\
Oat flakes & 3.0 & 3.0 \\
Wheat middlings & 0.4 & 0.4 \\
Fat (tallow and lard mixture) & 1.0 & 0.6 \\
Expelled soybean meal (450 g CP/kg) & 7.0 & 6.9 \\
Corn gluten feed & 1.0 & 0.9 \\
Sodium caseinate & 6.3 & 6.3 \\
Whey powder, sweet & 5.0 & 5.0 \\
Apple pomace, dried & 5.0 & 5.0 \\
L-lysine-HCl (79\%) & 0.21 & 0.21 \\
L-threonine (99\%) & 0.06 & 0.07 \\
Dicalcium phosphate & 0.42 & 0.40 \\
Calcium formate & 0.10 & 0.10 \\
Calcium carbonate & 0.61 & 0.01 \\
Sodium chloride & 0.28 & 0.30 \\
Vitamin trace element premix $^{1}$ & 0.40 & 0.40 \\
Natuphos 5,000 G $^{2}$ & 0.02 & 0.02 \\
Pellan $^{3}$ & 0.30 & 0.30 \\
\hline
\end{tabular}

${ }^{1}$ Supplied per kilogram of diet: vitamin $\mathrm{A}, 8,000 \mathrm{IU}$; vitamin $\mathrm{D}_{3}, 1,000$ IU; vitamin E, $25 \mathrm{mg}$; menadione, $3 \mathrm{mg}$; thiamine, $2 \mathrm{mg}$; riboflavin, 5 $\mathrm{mg}$; biotin, $0.1 \mathrm{mg}$; niacin, $20 \mathrm{mg}$; pantothenic acid, $15 \mathrm{mg}$; iron, $80 \mathrm{mg}$ as iron sulfate; iodine, $0.15 \mathrm{mg}$ as calcium iodate; copper, $6 \mathrm{mg}$ as copper sulfate; manganese, $10 \mathrm{mg}$ as manganese oxide; zinc, $75 \mathrm{mg}$ as zinc oxide; selenium, $0.2 \mathrm{mg}$ as sodium selenite.

${ }^{2}$ BASF (Ludwigshafen, Germany); provided 1,000 units Aspergillus niger phytase/kg diet; one phytase unit corresponds to the amount of enzyme that releases $1 \mu \mathrm{mol} \mathrm{P}$ from $5 \mathrm{mM}$ phytate $/ \mathrm{min}$ at $\mathrm{pH} 5.5$ and $37^{\circ} \mathrm{C}$.

${ }^{3}$ Pellan (Mikro-Technik, Bürgstadt, Germany) is a water soluble cellulose product used to facilitate feed pelleting.

\section{DISCUSSION}

Although the low dietary phytate P content of $1.8 \mathrm{~g} / \mathrm{kg}$ may have been the limiting factor for the release of $\mathrm{P}$ by the added phytase, the calculated $\mathrm{P}$ digestibility of $68 \%$ corresponds to previous $\mathrm{P}$ digestibility values using similar diets (Gutzwiller et al., 2011). The calculated dP concentration of $0.27 \%$ in the experimental diets, which corresponds to $0.19 \mathrm{~g} \mathrm{dP} / \mathrm{MJ} \mathrm{DE}$, is slightly below the 0.20 $\mathrm{g} \mathrm{dP} / \mathrm{MJ}$ DE required by pigs weighing 11 to $25 \mathrm{~kg}$ (NRC, 2012). The lower than recommended dietary dP concentration, which corresponds to levels used in Swiss pig feeds formulated to minimise $\mathrm{P}$ effluent, was chosen in order to detect possible dietary effects under the condition of a marginal $\mathrm{P}$ supply. It is known that the effect of different dietary $\mathrm{Ca}: \mathrm{P}$ ratios on growth performance and bone characteristics is more pronounced at marginal compared to high dietary P levels (Reinhardt and Mahan, 1986; Hall et al., 1991). Despite the marginal dP supply, the bone ash concentration of the experimental animals corresponds to the concentration of $50 \%$ to $53 \%$ ash in the fat-free DM reported by Koch et al. (1984), Traylor et al. (2005) and Adeola et al. (2006) in weanling and growing pigs fed diets containing adequate $\mathrm{Ca}$ and $\mathrm{P}$ levels.

The difference in phytase activity between diets $\mathrm{HCa}$ and LCa cannot be exclusively accounted for by the uncertainty of the analytical method used, which has a relative standard deviation for reproducibility of $15 \%$ (Gizzi et al., 2008). The reason for the larger than expected difference is unknown. Although BA had increased $\mathrm{P}$ digestibility in a previous experiment (Gutzwiller et al., 2011), and therefore might have modulated the effects of the Ca:P ratio on animal performance and mineral metabolism, no significant $\mathrm{BA} \times \mathrm{Ca}$ interaction on any of the tested parameters was observed in the present experiment. The effects of the two factors are therefore discussed separately.

\section{Effects of benzoic acid}

Benzoic acid increased the growth performance of the pigs, confirming the results of previous studies (Guggenbuhl et al., 2007; Torrallardona et al., 2007). Although BA significantly lowered the urinary $\mathrm{pH}$ from 7.4 to respectively 7.1 and 6.5 in treatments $\mathrm{HCa}+$ and $\mathrm{LCa}+$ the values of the pigs receiving the BA supplemented diets corresponded to the urinary $\mathrm{pH}$ of pigs exposed to a physiological dietary acid load (Budde and Crenshaw, 2003) and therefore reflect an undisturbed acid-base balance. Torrallardona et al. (2007) and Gutzwiller et al. (2011) reported urinary pH values below 5.5 in weanling pigs which were fed diets containing $0.5 \%$ BA. The higher dEB (135 vs $82 \mathrm{mEq} / \mathrm{kg}$ ) and the higher Ca concentration (5.7 and $7.7 \mathrm{~g} / \mathrm{kg}$ vs $5.3 \mathrm{~g} / \mathrm{kg}$ ) in the diets of the present compared to those of the previous experiment account for the higher urinary $\mathrm{pH}$ in the present compared to our previous experiment because both a high dEB and a high dietary $\mathrm{Ca}$ concentration increase the urinary $\mathrm{pH}$ in pigs (Canh et al., 1998). The fact that BA neither affected the serum AP activity, which is in contrast to our previous finding (Gutzwiller et al., 2011), nor the bone traits, suggests that BA does not impair bone metabolism of weanling pigs unless its addition decreases urinary $\mathrm{pH}$ to below 6 , a value associated with a reduced $\mathrm{Ca}$ retention in pigs (Patience and Chaplin, 1997).

The absence of any negative BA effect on bone characteristics confirms the findings of Sauer et al. (2009) and of Gutzwiller et al. (2011), who did not detect any negative effect of $\mathrm{BA}$ on bone ash concentration and breaking strength in pigs weighing 40 and $60 \mathrm{~kg}$, respectively. The effects of $\mathrm{BA}$ on bone traits of growingfinishing pigs reported by Bühler et al. (2010) are equivocal: Benzoic acid tended to reduce ash concentration in the metatarsal bones, but did not affect the breaking 
Table 2. Chemical composition of the four experimental diets, $\%$ as fed basis unless stated otherwise

\begin{tabular}{|c|c|c|c|c|}
\hline \multirow{3}{*}{ Item } & \multicolumn{4}{|c|}{ Ca concentration } \\
\hline & \multicolumn{2}{|c|}{ High $(\mathrm{HCa})$} & \multicolumn{2}{|c|}{ Low (LCa) } \\
\hline & + & - & + & - \\
\hline $\mathrm{CP}$ & 17.1 & 16.8 & 17.1 & 17.0 \\
\hline Crude fat & 3.5 & 3.8 & 4.0 & 3.5 \\
\hline Crude fiber & 2.7 & 3.0 & 2.8 & 2.9 \\
\hline Ash & 4.3 & 4.3 & 3.8 & 3.8 \\
\hline Calcium & 0.76 & 0.78 & 0.55 & 0.58 \\
\hline Phosphorus & 0.39 & 0.41 & 0.41 & 0.41 \\
\hline Phytate phosphorus & 0.17 & 0.18 & 0.20 & 0.18 \\
\hline Magnesium & 0.11 & 0.11 & 0.11 & 0.11 \\
\hline Potassium & 0.52 & 0.53 & 0.54 & 0.55 \\
\hline Sodium & 0.23 & 0.23 & 0.24 & 0.25 \\
\hline Chloride & 0.36 & 0.36 & 0.36 & 0.37 \\
\hline Phytase activity (FTU/kg) & 1,450 & 1,350 & 1,100 & 1,100 \\
\hline Lysine & 1.10 & 1.10 & 1.08 & 1.08 \\
\hline Methionine & 0.36 & 0.37 & 0.37 & 0.36 \\
\hline Cystine & 0.27 & 0.27 & 0.28 & 0.28 \\
\hline Tryptophan & 0.20 & 0.20 & 0.21 & 0.21 \\
\hline Threonine & 0.74 & 0.74 & 0.72 & 0.72 \\
\hline $\mathrm{DE}(\mathrm{MJ} / \mathrm{kg})$ & 14.0 & 14.0 & 14.0 & 14.0 \\
\hline Calcium:phosphorus ratio & 1.9 & 1.9 & 1.3 & 1.4 \\
\hline Dietary electrolyte balance $(\mathrm{mEq} / \mathrm{kg})$ & 129 & 133 & 139 & 141 \\
\hline
\end{tabular}

DE, calcium:phosphorus ratio and dietary electrolyte balance $\left(\mathrm{Na}^{+}+\mathrm{K}^{+}-\mathrm{Cl}^{-}\right.$, expressed in milliequivalents) were calculated while the other data represent analyzed values.

strength of the tibia, despite a significantly reduced tibial bone mineral density. In conclusion, the majority of published data do not show significant negative effects of BA on bone breaking strength and bone ash concentration, suggesting that the risk of reduced bone mineralization caused by this feed additive is low.

\section{Effects of the dietary Ca:P ratio}

The effects of the wide dietary $\mathrm{Ca}: \mathrm{P}$ ratio in diets $\mathrm{HCa}$ on feed intake, ADG, FCR as well as serum $\mathrm{Ca}$ and $\mathrm{P}$ concentration confirm results of Lei et al. (1994) and Qian et al. (1996) on the effects of a wide Ca:P ratio in phytasesupplemented weanling pig diets on growth performance and serum clinical chemistry. According to Suttle (2010), maximum growth in pigs is associated with a serum $\mathrm{P}$ concentration of at least $2.5 \mathrm{mmol} / \mathrm{L}$. All but one of the pigs fed the LCa diets, but only two thirds of the pigs fed the $\mathrm{HCa}$ diets had a serum $\mathrm{P}$ concentration above that threshold concentration, which may explain the growth-depressing effect of the $\mathrm{HCa}$ diets. An increase in serum $\mathrm{Ca}$ concentration, as observed in the pigs fed diets $\mathrm{HCa}$, is known to decrease serum parathyroid hormone concentration and to increase serum calcitonin concentration (Cooper et al., 1971), resulting in a reduced renal reabsorption of both $\mathrm{Ca}$ and $\mathrm{Mg}$ (Littledike and Goff, 1987). The increased urinary Ca:creatinine ratio observed in treatments $\mathrm{HCa}$ shows that urinary $\mathrm{Ca}$ excretion was increased in response to the increased serum $\mathrm{Ca}$ concentration. The decreased $\mathrm{Mg}$ concentration in the serum and in the bone ash of the animals on diets HCa may

Table 3. Effects of dietary calcium concentration and benzoic acid (BA) supplementation on growth performance from four to ten weeks of age $(n=17)$

\begin{tabular}{|c|c|c|c|c|c|c|c|c|}
\hline \multirow{3}{*}{ Item } & \multicolumn{4}{|c|}{ Ca concentration and BA supplementation } & \multirow{3}{*}{ SEM } & \multirow{2}{*}{\multicolumn{3}{|c|}{ p-value }} \\
\hline & \multicolumn{2}{|c|}{$\mathrm{HCa}$} & \multicolumn{2}{|c|}{$\mathrm{LCa}$} & & & & \\
\hline & + & - & + & - & & BA & $\mathrm{Ca}$ & $\mathrm{BA} \times \mathrm{Ca}$ \\
\hline Initial BW (kg) & 9.7 & 9.6 & 9.8 & 9.7 & 0.29 & 0.793 & 0.657 & 0.977 \\
\hline Final BW (kg) & 22.7 & 20.7 & 24.8 & 24.3 & 0.88 & 0.159 & 0.012 & 0.614 \\
\hline $\mathrm{ADFI}(\mathrm{g})$ & 524 & 451 & 567 & 513 & 23.8 & 0.009 & 0.034 & 0.691 \\
\hline $\mathrm{ADG}(\mathrm{g})$ & 329 & 284 & 370 & 343 & 17.6 & 0.051 & 0.007 & 0.628 \\
\hline $\mathrm{FCR}^{1}(\mathrm{~kg} / \mathrm{kg})$ & 1.60 & 1.64 & 1.55 & 1.50 & 0.044 & 0.885 & 0.027 & 0.334 \\
\hline
\end{tabular}

${ }^{1} \mathrm{FCR}=$ Feed conversion ratio (kg feed consumed per kg BW gain). 
Table 4. Effects of dietary calcium concentration and benzoic acid (BA) supplementation on serum and urine parameters

\begin{tabular}{|c|c|c|c|c|c|c|c|c|}
\hline \multirow{3}{*}{ Item } & \multicolumn{4}{|c|}{ Ca concentration and BA supplementation } & \multirow{3}{*}{ SEM } & \multirow{2}{*}{\multicolumn{3}{|c|}{ p-value }} \\
\hline & \multicolumn{2}{|c|}{$\mathrm{HCa}$} & \multicolumn{2}{|c|}{$\mathrm{LCa}$} & & & & \\
\hline & + & - & + & - & & BA & $\mathrm{Ca}$ & $\mathrm{BA} \times \mathrm{Ca}$ \\
\hline \multicolumn{9}{|l|}{ Serum $(n=17)$} \\
\hline $\mathrm{Ca}(\mathrm{mmol} / \mathrm{L})$ & 2.87 & 2.89 & 2.75 & 2.73 & 0.030 & 0.963 & $<0.001$ & 0.356 \\
\hline Phosphorus (mmol/L) & 2.60 & 2.69 & 3.47 & 3.30 & 0.089 & 0.648 & $<0.001$ & 0.155 \\
\hline Magnesium (mmol/L) & 1.20 & 1.21 & 1.29 & 1.27 & 0.022 & 0.869 & 0.002 & 0.458 \\
\hline Alkaline phosphatase (U/L) & 329 & 332 & 328 & 352 & 17.9 & 0.434 & 0.611 & 0.567 \\
\hline \multicolumn{9}{|l|}{ Urine $^{1}$} \\
\hline $\mathrm{pH}$ & 7.07 & 7.44 & 6.46 & 7.40 & $0.292^{\mathrm{a}}$ & 0.031 & 0.246 & 0.322 \\
\hline $\mathrm{Ca} /$ creatinine $(\mathrm{mmol} / \mathrm{mmol})$ & 2.75 & 3.69 & 0.96 & 1.66 & $0.655^{\mathrm{a}}$ & 0.214 & 0.006 & 0.855 \\
\hline P/creatinine (mmol/mmol) & 0.04 & 0.05 & 0.07 & 0.05 & $0.009^{\mathrm{a}}$ & 0.517 & 0.183 & 0.188 \\
\hline
\end{tabular}

${ }^{1}$ Urine samples could be collected at slaughter from 33 animals only (9 HCa+, 8 of each other treatment).

${ }^{\text {a }}$ SEM of the three treatments with eight replications.

be the result of either an increased urinary $\mathrm{Mg}$ excretion or of a decreased intestinal $\mathrm{Mg}$ absorption caused by the high dietary $\mathrm{Ca}$ concentration, as observed in the horse (Grace et al., 2003).

The increased bone ash concentration observed in the pigs fed diets $\mathrm{HCa}$ supports the finding of LétourneauMontminy et al. (2010) that widening the dietary $\mathrm{Ca}: \mathrm{P}$ ratio from 1.3 to 1.9 in a diet containing $0.56 \% \mathrm{P}$ supplemented with $1,000 \mathrm{FTU} / \mathrm{kg}$ phytase had no negative effect on $\mathrm{P}$ digestibility and significantly increased bone ash concentration in weanling pigs. On the other hand Qian et al. (1996) reported a negative effect on P digestibility and bone mineralization of weanling pigs when the Ca:P ratio of a diet containing $0.45 \% \mathrm{P}$ supplemented with $1,000 \mathrm{FTU} / \mathrm{kg}$ phytase was increased from 1.2 to 2 . A meta-analysis of $P$ utilization in pigs (Létourneau-Montminy et al., 2012) which shows that increasing dietary Ca negatively affects retained $\mathrm{P}$ when diets have a low concentration of nonphytate $\mathrm{P}$, but increases retained $\mathrm{P}$ in diets having a high concentration of non-phytate $\mathrm{P}$, explains the conflicting effects of a wide $\mathrm{Ca}: \mathrm{P}$ ratio on bone mineralization reported by Qian et al. (1996) and by Létourneau-Montminy et al. (2010). The increased bone mineralization of the pigs in the present study fed low $\mathrm{P}$ diets with a high $\mathrm{Ca}$ concentration (diets $\mathrm{HCa}$ ) is in contradiction to the results of this meta- analysis. $\mathrm{P}$ digestibility was presumably less impaired than FCR by the wide $\mathrm{Ca}: \mathrm{P}$ ratio of diets $\mathrm{HCa}$, resulting in an increased amount of absorbed $\mathrm{P}$ per $\mathrm{kg} \mathrm{BW}$ gain. The higher phytase activity analyzed in diets $\mathrm{HCa}$, as compared to diets LCa, may have contributed to the positive effect on bone mineralization. However, this effect was presumably of minor importance, because the amount of phytate $\mathrm{P}$ released per unit of phytase markedly declines with increasing dietary phytase concentration (Paditz et al., 2004).

The hypothesis tested that the Ca:P ratio in phytasesupplemented feeds for growing pigs should be wider than 1.3:1 in order to maximise bone mineralization could not be verified in the present study because the effects of the increased Ca supply, of the reduced feed conversion ratio and the differences in dietary phytase activities on bone mineralization cannot be separated. However, the results show that a dietary $\mathrm{Ca}: \mathrm{P}$ ratio of $1.9: 1$ in a low $\mathrm{P}$ diet reduces growth performance to such an extent that such a feeding regimen cannot be recommended for economic reasons. The question as to the effects of $\mathrm{Ca}: \mathrm{P}$ ratios wider than 1.3:1 but lower than 1.9:1 in phytase supplemented low $\mathrm{P}$ diets on growth performance, $\mathrm{Ca}$ and $\mathrm{P}$ digestibility and bone mineralization merits further investigation.

Table 5. Effects of dietary calcium concentration and benzoic acid (BA) supplementation on characteristics of the tibia $(n=17)$

\begin{tabular}{|c|c|c|c|c|c|c|c|c|}
\hline \multirow{3}{*}{ Item } & \multicolumn{4}{|c|}{ Ca concentration and BA supplementation } & \multirow{3}{*}{ SEM } & \multirow{2}{*}{\multicolumn{3}{|c|}{ p-value }} \\
\hline & \multicolumn{2}{|c|}{$\mathrm{HCa}$} & \multicolumn{2}{|c|}{$\mathrm{LCa}$} & & & & \\
\hline & + & - & + & - & & BA & $\mathrm{Ca}$ & $\mathrm{BA} \times \mathrm{Ca}$ \\
\hline Breaking strength $\left(\mathrm{N}^{1}\right)$ & 1,329 & 1,266 & 1,377 & 1,341 & 46.7 & 0.298 & 0.192 & 0.779 \\
\hline Breaking strength (N/kg BW) & 57.8 & 59.4 & 55.7 & 56.7 & 1.62 & 0.426 & 0.142 & 0.857 \\
\hline Ash (\% in fat free DM) & 53.1 & 53.3 & 51.4 & 51.2 & 0.74 & 0.952 & 0.013 & 0.776 \\
\hline Calcium (\% in ash) & 40.6 & 39.5 & 39.5 & 39.3 & 0.41 & 0.132 & 0.129 & 0.246 \\
\hline Phosphorus (\% in ash) & 19.1 & 19.1 & 19.4 & 19.0 & 0.20 & 0.361 & 0.548 & 0.283 \\
\hline Magnesium (\% in ash) & 0.90 & 0.92 & 0.98 & 0.98 & 0.02 & 0.833 & $<0.001$ & 0.534 \\
\hline
\end{tabular}

${ }^{1} \mathrm{~N}=$ Newton. 


\section{REFERENCES}

Adeola, O., O. A Olukosi, J. A. Jendza, R. N. Dilger, and M. R. Bedford. 2006. Response of growing pigs to Peniophora lyciiand Escherichia coli-derived phytases or varying ratios of calcium to total phosphorus. Anim. Sci. 82:637-644.

Agroscope Liebefeld-Posieux (ALP). 2004. Apports alimentaires recommandés et tables de la valeur nutritive des aliments pour porcs. LMZ, Centrale des Moyens d'Enseignement Agricole, Zollikofen, Switzerland.

Arnett, T. 2003. Regulation of bone cell function by acid-base balance. Proc. Nutr. Soc. 62:511-520.

Budde, R. A. and T. D. Crenshaw. 2003. Chronic metabolic acid load induced by changes in dietary electrolyte balance increased chloride retention but did not compromise bone in growing swine. J. Anim. Sci. 81:197-208.

Bühler, K., A. Liesegang, B. Bucher, C. Wenk, and J. Broz. 2010. Influence of benzoic acid and phytase in low-phosphorus diets on bone characteristics in growing-finishing pigs. J. Anim. Sci. 88:3363-3371.

Canh, T. T., A. J. A. Aarnink, Z. Mroz, A. W. Jongbloed, J. W. Schrama, and M. W. A. Verstegen. 1998. Influence of electrolyte balance and acidifying calcium salts in the diet of growing-finishing pigs on urinary $\mathrm{pH}$, slurry $\mathrm{pH}$ and volatilisation from slurry. Livest. Prod. Sci. 56:1-13.

Cooper, C. W., L. J. Deftos, and J. T. Potts. 1971. Direct measurement of in vivo secretion of pig thyrocalcitonin by radioimmunoassay. Endocrinology 88:747-754.

Crenshaw, T. D. 2001. Calcium, phosphorus, vitamin D, and vitamin $\mathrm{K}$ in Swine nutrition. In: Swine Nutrition, $2^{\text {nd }} \mathrm{Ed}$. (Ed. A. J. Lewis and L. L. Southern). CRC Press, Boca Raton. pp. 187-212.

Fammatre, C. A., D. C. Mahan, A. W. Fetter, A. P. Grifo, and J. K. Judy. 1977. Effects of dietary protein, calcium and phosphorus levels for growing and finishing swine. J. Anim. Sci. 44:65-71.

Gizzi, G., P. Thyregod, C. von Holst, G. Bertin, K. Vogel, M. Faurschol-Isaksen, R. Betz, R. Murphy, and B. Brandt. 2008. Determination of phytase activity in feed: Interlaboratory study. J. AOAC Int. 91:259-267.

Grace, N. D., C. W. Rogers, E. C. Firth, T. L. Faram, and H. L. Shaw. 2003. Digestible energy intake, dry matter digestibility and effect of calcium intake on bone parameters of thoroughbred weanlings in New Zealand. NZ Vet. J. 51:165173.

Guggenbuhl, P., A. Seon, A. Pinon Quintana, and C. Simoes Nunes. 2007. Effects of dietary supplementation with benzoic acid $\left(\right.$ VevoVitall $\left.{ }^{\circledR}\right)$ on the zootechnical performance, the gastrointestinal microflora and the ileal digestibility of the young pig. Livest. Sci. 108:218-221.

Gutzwiller, A., H. D. Hess, A. Adam, D. Guggisberg, A. Liesegang and P. Stoll. 2011. Effects of a reduced calcium, phosphorus and protein intake and of benzoic acid on calcium and phosphorus metabolism of growing pigs. Anim. Feed Sci. Technol. 168:113-121.

Hall, D. D., G. L. Cromwell, and T. S. Stahly. 1991. Effects of dietary calcium, phosphorus, calcium:phosphorus ratio and vitamin $\mathrm{K}$ on performance, bone strength and blood clotting status of pigs. J. Anim. Sci. 69:646-655.

Hansen, C. F., G. Sorensen, and M. Lyngbye, 2007. Reduced diet crude protein, benzoic acid and inulin reduced ammonia, but failed to influence odor emission from finishing pigs. Livest. Sci. 109:228-231.

Koch, M. E., D. C. Mahan, and J. R. Corley. 1984. An evaluation of various biological characteristics in assessing low phosphorus intake in weanling swine. J. Anim. Sci. 59:15461556.

Kornegay, E. T. 2001. Digestion of phosphorus and other nutrients: the role of phytases and factors influencing their activity. In: Enzymes in Farm Animal Nutrition (Ed. M. R. Bedford and G. G. Partridge). CAB International, Wallingford, UK. pp. 237-271.

Lantzsch, H. J., S. Wjst, and W. Drochner. 1995. The effect of dietary calcium on the efficacy of microbial phytase in rations for growing pigs. J. Anim. Physiol. Anim. Nutr. 73:19-26.

Lei, X. G., P. K. Ku, E. R. Miller, M. T. Yokoyama, and D. E. Ullrey. 1994. Calcium level affects the efficacy of supplemental microbial phytase in corn-soybean meal diets of weanling pigs. J. Anim. Sci. 72:139-143.

Létourneau-Montminy, M. P., A. Narcy, M. Magnin, D. Sauvant, J. F. Bernier, C. Pomar, and C. Jondreville. 2010. Effect of reduced dietary calcium concentration and phytase supplementation on calcium and phosphorus utilization in weanling pigs with modified mineral status. J. Anim. Sci. 88:1706-1717.

Létourneau-Montminy, M. P., C. Jondreville, D. Sauvant, and A. Narcy. 2012. Meta-analysis of phosphorus utilization by growing pigs: Effect of dietary phosphorus, calcium and exogenous phytase. Animal 6:1590-1600.

Littledike, E. T. and J. Goff. 1987. Interactions of calcium, phosphorus, magnesium and vitamin $\mathrm{D}$ that influence their status in domestic meat animals. J. Anim. Sci. 65:1727-1743.

National Research Council. 2012. Nutrient Requirements of Swine. 11th Ed. National Academy Press, Washington, DC.

Paditz, K., H. Kluth, and M. Rodehutscord. 2004. Relationship between graded doses of three microbial phytases and digestible phosphorus in pigs. Anim. Sci. 78:429-438.

Patience, J. F. and R. K. Chaplin. 1997. The relationship among dietary undetermined anion, acid-base balance, and nutrient metabolism in swine. J. Anim. Sci. 75:2445-2452

Qian, H., E. T. Kornegay, and D. E. Conner. 1996. Adverse effects of wide calcium:phosphorus ratios on supplemental phytase efficacy for weanling pigs fed two dietary phosphorus levels. J. Anim. Sci. 74:1288-1297.

Reinhardt, G. A. and D. C. Mahan. 1986. Effects of various calcium:phosphorus ratios at low and high dietary phosphorus for starter, grower and finishing swine. J. Anim. Sci. 63:457466

Sauer, W., M. Cervantes, J. Yanez, B. Araiza, G. Murdoch, A. Morales, and R. T. Zijlstra. 2009. Effect of dietary inclusion of benzoic acid on mineral balance in growing pigs. Livest. Sci. 122:162-168

Suttle, N. 2010. Mineral Nutrition of Livestock. 8th Ed. CABI, Wallingford, GB.

Torrallardona, D., I. Badiola, and J. Broz. 2007. Effects of benzoic acid on performance and ecology of gastrointestinal microbiota in weanling piglets. Livest. Sci. 108:210-213.

Traylor, S. L., G. L. Cromwell, and M. D. Lindemann. 2005. Bioavailability of phosphorus in meat and bone meal for swine J. Anim. Sci. 83:1054-1061. 